\title{
Quantitative Analysis of Dynamic Risk Factors for Shipping Operations
}

\author{
Serap GÖKSU ${ }^{1}$, Özcan ARSLAN ${ }^{1}$ \\ ${ }^{1}$ Istanbul Technical University, Faculty of Maritime, Turkey \\ sgoksu@itu.edu.tr; ORCID ID: https://orcid.org/0000-0002-3524-3606 \\ arslano@itu.edu.tr; ORCID ID: https://orcid.org/0000-0003-4769-6941 \\ Corresponding Author: Serap GOKSU
}

\begin{abstract}
Risk assessment activities in maritime transportation are mostly done through fixed risk assessment forms. However, during maritime operations, many different dynamic factors such as visibility, the time period during which the operation is carried out, weather, current speed, tidal status, traffic density, etc. can increase these risks. These dynamic risks are not included in the existing risk assessment forms.

In this study, the dynamic factors that increase the risks in ship operations were determined, and to what extent the variables in the operation quantitatively increased various risks was examined through the survey study conducted. Risk coefficients were collected through a survey study, as a data collection tool, conducted on seafarer who participated in ship operations. Consequently, the type of risk assessment to be performed in accordance with the dynamics was evaluated by adding dynamic risks to the possible static risks in cargo operations.
\end{abstract}

\section{Keywords}

Maritime Safety, Ship Operation, Risk, Dynamic Risk Assessment.

\section{Introduction}

More than 80 percent of the world trade volume is transported by merchant ships. In early 2019, the total world fleet capacity was 1.97 billion DWT, corresponding to a growth of 2.61 percent [1]. Maritime transport is regarded as the most preferred type of transportation in the world because of the fact that it can carry large amounts of cargo at one time, there is no international border-crossing problem, the loss of goods is at a minimal level and it is safer than other types of transportation [2].

Parallel to the technological and social developments, industrialization and population growth, demand for energy, goods, and food are increasing each day. This brings with it an increase in the number of ships, ship sizes, ship speed and therefore an increase in maritime traffic. The risks neglected regarding ships, in which large investments are made to

To cite this article: Goksu, S. \& Arslan, O. (2020). Quantitative Analysis of Dynamic Risk Factors for Shipping Operations. Journal of ETA Maritime Science, 8(2), 86-97. 
have the potential to cause high costs and disasters. Proper assessment of the risks in such systems forms the basis for taking necessary measures effectively [3].

Occupational activities in many industrial fields provide various benefits to human life. However, such activities may contain potential risks during their routine operations. Therefore, some unexpected errors can occur in accordance with relevant operational tasks. Nevertheless, these errors may have crucial importance as they could lead to very costly results such as loss of assets, operational resources or even human life, which can be affected directly or indirectly. The problem, here, is how to establish human control over potentially dangerous technical operations [4]. Similarly, ship operations may contain many risks due to the hazardous working environment and many exhaustive operations.

Many resolutions, codes, and practices have been made and performed by maritime authorities in order to identify and prevent risks in the maritime industry, and riskreducing or preventive control measures have been proposed. However, it is seen that many conventions, rules, and codes in the maritime industry were made after accidents. Although continuous measures are taken by maritime authorities to reduce risks, accidents continue to occur.

The disaster that took place in the offshore platform of Piper Alpha in the North Sea in 1988 caused 167 crew members to lose their lives. After the accident, which was the worst disaster in an offshore plant in terms of casualties [5], efforts were made by the International Maritime Organization (IMO) to evaluate safety in the maritime industry and the "Formal Safety Assessment" practice was developed, which was in the form of a guide,. The Formal Safety Assessment Guidelines were approved in 2002 for the IMO to use them in the rule-making process
[6]. The guidelines were replaced by MSC/Circ.1180-MEPC/Circ.474 and MSCMEPC.2/Circ.5. and, MSC-MEPC.2/Circ.12/ Rev.2 is the currently-used guidelines [7-9]. The FSA is used as a basis by member states or related committees in the decisionmaking process of the changes to be made on IMO contracts [10]. It aims to make the decisions taken by IMO more effective and to take measures before accidents occur by adopting a proactive approach [11].

Moreover, the assessment of the risks related to ships was made by companies and static risk assessment forms which has been prepared in order to minimize the effects of these risks. Other than the identified risks, the maritime industry is also under the influence of many dynamic risks such as meteorological events [12], environmental status [13], ship structure [14] and ship stability [15] and the type of operation [16]. When these risks are not taken into account, serious losses are predicted to occur. However, during maritime operations many different dynamic factors such as visibility status, the time period during which the operation is carried out, weather status, current speed, tidal status, traffic density, etc. can increase these risks. These dynamic risks are not included in the existing risk assessment forms. Therefore, the necessity to evaluate under which conditions the dynamic risks changed numerically has emerged. It is important for the safety of the operation to be carried out to update the existing data when new data on both static risks and dynamic risks are available.

Within this context, the paper is organized as follows. The literature review on dynamic risk assessment is presented in Chapter 2. The proposed model is explained and the data obtained are presented in Chapter 3. The experimental study involving the sensitivity analysis to evaluate the survey study and confirm the results is described in Chapter 4. As a case study; the 
additional risks brought by the dynamic risks affecting cargo operation are examined in Chapter 5. In the last chapter, the results are discussed and recommendations are offered for future research.

\section{Literature Review}

According to IMO, the only way to take action before a disaster occurs is to use the process known as the Formal Safety Assessment (FSA). IMO defines FSA as a combination of the occurrence probability of danger and the severity of the result [17]. FSA is a risk-based assessment method. It is important to know how to control the system functions and to establish how to develop corrective actions in order to prevent operational-level risks in the system functions so that operations can be carried out in a safe working environment [18].

Because maritime accidents occur due to continuous and variable parameters, risk factors can trigger different incidents and cause different dangers [19]. Risk assessment, in this regard, plays an important role in preventing accidents. Risk assessment is a procedure called regulatory impact diagrams. A regulatory impact diagram may represent "reducing and corrective control measures" such as "probability" and "severity" of an accident, evacuation of people from an affected ship, control and cleaning of the pollution, etc [20]. The outputs obtained from the risk assessment form the basis for the operations carried out on board.

The addition of significant uncertainties and variable factors to the static risks of maritime operations creates a complex and dynamic working environment. Although conventional risk assessment methods play an important role in identifying major risks and ensuring safety, they have a static structure [21]. In an evergrowing environment, risk assessment methodologies and practices have made progress towards a dynamic direction in order to address risk-related issues, support operations and overcome the limitations of conventional techniques. This allows for continuous integration with more accurate data and an optimum risk picture [22]. Dynamic risk assessment (DRA) aims to pay attention to new risk concepts and early warnings and to systematically update related risks and to provide more flexibility [3]. In this way, it informs decision-makers more efficiently for taking early actions [23]. Dynamic risk assessment forms the basis of next-generation risk assessment and risk management approaches [24]. The implementation of procedures and the selection of equipment in cases where dynamic risks emerge will form the basis for determining the techniques to be used for managing the process.

In recent years, many DRA studies, especially on offshore systems have been carried out in the maritime industry. For instance; Ren et al. evaluated the real-time collision risk of ships using the SAMSON risk model and fuzzy logic method [25]. Similarly, Yeo et al., using the dynamic risk assessment methodology based on Bayes Networks, investigated the reasons for the situations that caused collisions, leaks and landing accidents in the unloading operations of LNG carriers in a terminal [26]. Zhang et al, who transformed the BowTie model into Dynamic Bayes Networks, examined the MPD (managed pressured drilling) operations in the offshore oil and gas fields [27].

In another study conducted by Pak et al; the risk factors affecting safety in ports such as weather status, features of channels and types of ships, etc. were evaluated in terms of Korea [28]. Bi et al., who used the MLD (Mater Logic Diagram) dynamic risk assessment model, investigated potential loss due to oil spill and the problems such as environmental damage, loss of goods, health impact and social impact, 
arising after it [29]. Eide et al. estimated the environmental risk of drift grounding accidents for oil tankers using the dynamic risk approach with real-time and projected risk modeling and investigated the probability of grounding and the impact of oil spillage on the coastline [30]. They aimed to provide a dynamic risk-based positioning of tugboats, using real-time and projected risk models to accommodate the drifting ship with effective support. Dai et al. developed a dynamic risk pre-assessment system model in order to provide early risk warning for traffic safety in marine spaces with limited visibility using the fuzzy system method [31]. Rokseth et al. focused on Dynamic Positioning (DP) systems, where automated control made risk assessment difficult [32]. It is shown that the risk depends on parameters such as time-dependent variables and status variables, failures and event timing. Basic requirements are proposed for operational online risk assessment frameworks. Balmat et al. asserted that a ship's individual risk index can be used in real-time to detect a risky ship [33]. They obtained the fuzzy risk factor from the ship's static risk factor and dynamic risk factor by performing the Maritime Risk Assessment (MARISA) with a fuzzy logic approach. Yan et al. investigated the dynamic obstruction risks of the Yangtze River, in which inland waterway transport is carried out, through the CBR and F-TOPSIS hybrid study [34]. CBR (cost-benefit ratio) was applied to select the most cost-effective one in a dynamic risk environment; and the F-TOPSIS method to assess the dynamic risks of inland waterway obstructions.

\section{Methodology}

The risks, probability, and effect categories of relevant operations are determined and rated with the risk matrix that is created as a result of the risk assessment [35]. The risks are expressed in numerical values in order to be prioritized.
The risk-reducing activities or control measures are determined according to the definitions that correspond to the numbers in the matrix.

A Questionnaire was created to determine the dynamic risks that were identified in the present study. The expressions in the measurement tools were based on a 5-Point Likert Scale (1= Very Low Risk, 2= Low Risk, 3= Moderate Risk, 4= High Risk, 5= Very High Risk). The Statistical Package Program for Social Sciences (SPSS) 26.0 was used for the statistical analysis of the data.

\subsection{Determining The Dynamic Risk Factors}

Hazard Identification (HAZID) is an analytical technique [36] used to identify the dangers that would lead to a dangerous event if adequate precautions are not taken, and constitutes the first step of any risk evaluation [37]. Different methods are used for HAZID. In the present study, the Brainstorming Method (BS) was used. The Brainstorming Method was first used by a publicist named Osborn in 1957 [38]. Brainstorming, which is used as a tool for enhancing creativity in corporate settings, was also used in the following years in different areas because of its ability to obtain a large number of ideas [39].

The human element also plays an important role in the areas where there is operational activity on ships. A mechanical failure that creates an insecure condition that can cause a human error or an accident can be defined as a triggering event [40]. In the literature; within the scope of risk assessment, many studies focusing on human element issues and using methodological approaches have been conducted. One of these studies, Arslan et al., examined the relationship between the factors affecting the fatigue level of navigational officers and marine accidents, using the SWOT analysis method [40]. 
Ylldırım et al., used the Analytic Hierarchy Process (AHP) method to identify human errors that caused landing accidents on container ships [41]. Similarly, Arslan et al., analyzed the accidents that occurred during loading and unloading operations at tanker terminals with the Fault Tree Analysis (FTA) method in terms of the human element and tested the results with Monte Carlo Simulation [42]. In addition, Kandemir et al., examined the role of human error during the revision of heavy fuel oil (HFO) purifier with the Shipboard Operation Human Reliability Analysis (SOHRA) approach [43]. Demirel examined the probability of human error in possible faults in gas turbine systems with the Cognitive Reliability Error Analysis Model (CREAM) method [44]. In this study, the human element is not included in the research.

The risk factors were determined for each group of operations with a detailed literature review and by receiving the opinions of experts in the field through BS. The risk factors may vary according to operation groups. The risk factor that did not affect or that was not suitable for the ship operation was not considered for that group of operations. As a result of HAZID,

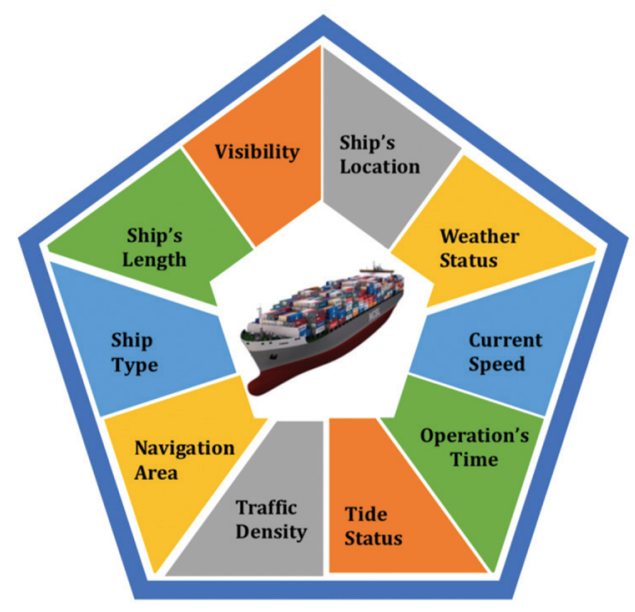

Figure 1: Structure for Dynamic Risk Factors
10 hazards were examined for quantitative risk assessment in terms of the Risk Index. The identified risk factors are shown in Figure 1.

The risk factors were classified as part of the visibility, weather status, time frame of the operation, the speed of the currents, tidal status, traffic density, location of the ship, and the area where the navigating was carried out (Figure 2). The size and type of the ship were classified as non-environmental factors. Visibility was classified as Visibility 1 (Thick Fog), Visibility 2 (Fog), Visibility 3 (Moderate Fog), Visibility 4 (Thin fog/Mist), Visibility 5 (Poor Visibility), and Visibility 6 (Good Visibility). The wind speed, wind direction, and sea status were classified under the weather group, which was the title of a single factor. 1-3 Beaufort, 4-6 Beaufort, 7-10 Beaufort and 11+ Beaufort subitems were given for the evaluation of the weather status. The time period during which the operation was carried out was classified as day and night. The location of ship is classified as being moored at berth/ terminal/port, at anchor, coastal/restricted waters, offshore, near coastal waters/gulf, open seas, narrow canals, straits, and in traffic separation zones. The tidal status was

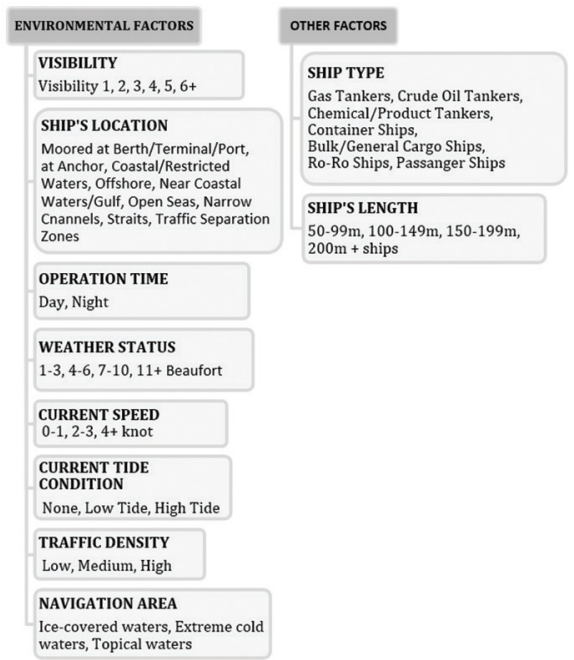

Figure 2: Dynamic Risk Factor' Classification 
evaluated for high and low tides. The speed of the current was classified according to its being $0-1,2-3,4+$ knots. The traffic density is classified as low, medium and high traffic. The navigating area was classified as icy waters, cold waters, and tropical waters. The length of ship was classified as $50-99 \mathrm{~m}$, $100-149 \mathrm{~m}, 150-199 \mathrm{~m}, 200 \mathrm{~m}$ and above. The ship type was classified as gas tanker, crude oil tanker, container ships, chemical/ product tanker, bulk/general cargo ships, ro-ro ships, and passenger ships.

\subsection{Data collection}

In this study, a questionnaire was designed and used as the data collection tool for the Turkish seafarers who participated in ship operations. The questionnaire consisted of 88 questions. The questions were intended to determine the factors that affected ship operations according to changing conditions. At first, responses from participants have been gathered to learn about their gender, proficiency and sea experience. In addition, the participants were asked to make evaluations about visibility, location of the ship, time of the operation, the weather, current speed, tidal status, traffic density of the port, ship size, and ship type for 11 different operations groups.

The questionnaire was conducted electronically and with Face-to-Face Interview Method between December 2019 and January 2020. The questionnaires returned from 56 seafarers who were actively working and who had experience for each operation.

The fact that the study was conducted only by the seafarers who had experience on all the operations on board, and that the data were limited to this sampling constitute the limitations of the present study.

\subsection{Dynamic risk assessment}

80 frequent operations that are carried out on board were classified into 11 basic operation groups with the help of the experts. These basic operation groups are cargo operations, mooring/unmooring/ rope/anchoring operations, general maintenance/repair operations, fuel change operations, ballasting/ de-ballasting/ ballast exchange operations, operations which are carried out during navigation, operations which are carried out on the deck, emergency operations, equipment failure operations, main and auxiliary machine operations, and other operations.

The study consist of three stages (Figure 3 ). The questionnaire was designed and the data obtained were analyzed with the SPSS Program.

The Cronbach's Alpha coefficient is

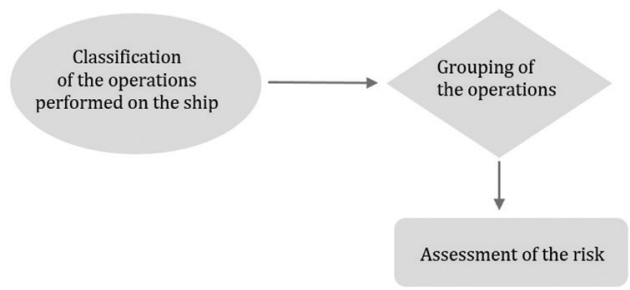

Figure 3: Stages of the Study

based on the number of questions on a scale and on the mean correlation among these reflecting the degree to which these questions measure a common point [45]. This coefficient varies between 0 and 1 and can be used to define the reliability of an analysis. Nunally (1978) reported that the value of 0,7 was an acceptable reliability coefficient [46]. The Cronbach's Alpha Internal Consistency Coefficient that was calculated on the questionnaire data was found to be 0,98 (Table 1 ). In this respect, the reliability rate of the survey was 98\%. The Cronbach's Alpha value and the reliability of the survey being above 0,7 shows that it is within reliable values.

Table 1: Reliability Statistics

\begin{tabular}{|l|l|}
\hline Cronbach's Alpha & N of Items \\
\hline 0,986 & 371 \\
\hline
\end{tabular}


A total of $89,3 \%$ of the seafarer who participated in the questionnaire were male (50), and 10,7\% were female (7). When the proficiency status of the participants was evaluated, it was determined that $43,64 \%$ (25) were Oceangoing Master, 23,64\% (13) Oceangoing Chief Officer, 16,36\% (9) were Oceangoing Watchkeeping Officer, 3,64\% (2) were Oceangoing Chief Engineer, 5,45\% (3) Oceangoing Second Engineer, 5,45\% (3) Oceangoing Engineer Officer, 1,82\% (1) was Captain. In terms of professional experience, it was determined that 20\% (11) had 17+ years' experience, 16,7\% (9) had 12-16 years' experience, $27,3 \%$ (15) had 8-11 years' experience, $20 \%$ (11) had 4-7 years' experience, $16,6 \%$ (9) had 3 years and less experience. The mean marine experience of the seafarer who participated in the questionnaire was 10,3 years.

\section{Finding and Discussion}

In the present study, the risk coefficients of the risk factors for ship operations were determined. The priority or ranking of the measures that will be considered to decrease or completely eliminate these risks will be determined with the risk coefficients. The control measures will be determined to control and completely eliminate the effects of these risks with a proactive approach and to control the possible risks that affect the safety of the ship during the operation.

The basic purpose of the present study was to create Dynamic Risk Check Lists considering the probability of dynamic risks of the abovementioned operations becoming a problem and to reduce the effects by determining the risks before they pose hazards.
The risk values of the visibility on ship operations are given in Table 2. It is seen in the table that when visibility drops below 3 in cargo operations, the risk increases rapidly. When visibility drops, the risks that will be posed by loading and emptying equipment on ships may not be predicted. The staff on the deck may not notice the dangers around, and depending on this, negative outcomes may increase rapidly. For this reason, in case of a significant decrease in visibility, the operation must be stopped or reduced to a safe speed. The staff must be informed about possible risks, and the number of the personnel on the deck must be increased. Pak et al. [28] stated that captains were more affected by weather and sea conditions among all port safety factors and that fog was the most important factor affecting air/sea conditions.

The risk values about the weather status on ship operations are given in Table 3. In this respect, when the ship is at the port, it is seen that if the wind force is 1-3 Beaufort, there is low risk; if the wind force is 4-6 Beaufort, there is moderate risk; and when the wind force rises above 6 Beaufort, there is a very strong risk. Loading and discharging operations must be carried out when the wind force is below 5 Beaufort. Operations must be carried out with maximum care in wind force above Beaufort 6. It was evaluated that the risks will increase above 6 Beaufort. It is important to take additional measures to reduce the risks, like increasing the number of staff on the deck, increasing the number of ropes, continuous watch, and informing the crew members on board. Severe weather and sea status play important causal roles in ship accidents. Zhang et al. [47] stated that

Table 2: Mean of Visibility Status Risk Factor

\begin{tabular}{|l|l|l|l|l|l|l|}
\hline $\begin{array}{l}\text { Ship } \\
\text { Operations }\end{array}$ & Visibility $\mathbf{1}$ & Visibility $\mathbf{2}$ & Visibility $\mathbf{3}$ & Visibility $\mathbf{4}$ & Visibility $\mathbf{5}$ & Visibility $\mathbf{6}$ \\
\hline $\begin{array}{l}\text { Cargo } \\
\text { Operations }\end{array}$ & 4,17 & 3,61 & 2,68 & 2,08 & 2,36 & 1,56 \\
\hline
\end{tabular}


Table 3. Mean of Weather Status Risk Factor

\begin{tabular}{|l|l|l|l|l|}
\hline Ship Operations & 1-3 Beaufort & 4-6 Beaufort & 7-9 Beaufort & 11+ Beaufort \\
\hline Cargo Operations & 1,96 & 3,1 & 4,26 & 4,84 \\
\hline
\end{tabular}

when the weather and sea status, which pose a relatively low potential hazard, meet certain conditions, the associated sea conditions may cause a risk for operational activities.

The risk values at the time of the operation are given in Table 4. It is seen in the table that cargo operations are riskier at night. In case of the operations are carried out at nights, further lighting of the deck and informing the crew members about possible risks are important.

Table 4: Mean of Operation's Time Risk Factor

\begin{tabular}{|l|c|c|}
\hline $\begin{array}{l}\text { Ship } \\
\text { Operations }\end{array}$ & Day & Night \\
\hline $\begin{array}{l}\text { Cargo } \\
\text { Operations }\end{array}$ & 2,45 & 3,64 \\
\hline
\end{tabular}

The risk values of the speed of the currents and the tidal status on ship operations are given in Table 5 and Table 6 , respectively. It was evaluated that the risks would increase if the values of the current speed exceed 1 knot in the port. In this case, the numbers, conditions, types and correct positioning of the ropes have become more important. In case of tidal currents, the tensions on the ropes will vary because of the tidal currents and the change in the tidal height. Fast changing of tidal height poses another risk for cargo operations. Tidal status can restrict loading operations. Tanker ships must also care about cargo hoses and arms during operations. The crew members must be informed about the speed of the currents, their directions, low and high tide times. The ropes must be adjusted considering high and low water.

Table 5: Mean of Current Speed Risk Factor

\begin{tabular}{|l|c|c|c|c|}
\hline $\begin{array}{l}\text { Ship } \\
\text { Operations }\end{array}$ & None & $\begin{array}{c}\mathbf{0 - 1} \\
\mathbf{k n o t}\end{array}$ & $\begin{array}{c}\mathbf{2 - 4} \\
\mathbf{k n o t}\end{array}$ & $\begin{array}{c}\mathbf{4 +} \\
\mathbf{k n o t}\end{array}$ \\
\hline $\begin{array}{l}\text { Cargo } \\
\text { Operations }\end{array}$ & 1,5 & 1,92 & 2,8 & 3,96 \\
\hline
\end{tabular}

Table 6: Mean of Tidal Status Risk Factor

\begin{tabular}{|l|c|c|c|}
\hline $\begin{array}{l}\text { Ship } \\
\text { Operations }\end{array}$ & None & Low Tide & High Tide \\
\hline $\begin{array}{l}\text { Cargo } \\
\text { Operations }\end{array}$ & 1,52 & 3,29 & 3,33 \\
\hline
\end{tabular}

The operational risk values for ship types are given in Table 7. It was evaluated that the risks in tanker ships were riskier than in other types of ships. It was also evaluated that, among other tanker types, cargo operations in gas tankers and chemical substance tankers were riskier. Pak et al. [28] stated that the most risky ship type is the second most important ship type of tanker ro-ro ships, in terms of port security.

This paper mainly focuses dynamic risk during cargo operations. When the recent part of the study considered the main dynamic risk are summarized below. The significant increases of dynamic risks are in condition of when the visibility is reduced from 4 to 3 ; the wind force increased up

Table 7. Mean of Ship Type Risk Factor

\begin{tabular}{|l|c|c|c|c|c|c|}
\hline $\begin{array}{l}\text { Ship } \\
\text { Operations }\end{array}$ & Gas Tanker & $\begin{array}{c}\text { Crude Oil } \\
\text { Tanker }\end{array}$ & $\begin{array}{c}\text { Chemical/ } \\
\text { Product } \\
\text { Tanker }\end{array}$ & $\begin{array}{c}\text { Container } \\
\text { Ship }\end{array}$ & $\begin{array}{c}\text { Bulk/ } \\
\text { General } \\
\text { Cargo Ship }\end{array}$ & Ro-Ro Ship \\
\hline $\begin{array}{l}\text { Cargo } \\
\text { Operations }\end{array}$ & 4,59 & 3,98 & 4,21 & 2,71 & 2,47 & 2,47 \\
\hline
\end{tabular}


to 4-6 Beafourt scale; when the ship is in narrow channels or straits; at nights; when the current speed or tide current speed is more than 1 knots; in heavy traffic; in icecovered waters; when the ship type is gas tankers and chemical tankers and ships length is $200 \mathrm{~m}$ and above.

\section{Conclusion}

In this study, the purpose was to measure the dynamic risk factors in ship operations. For this purpose, the examination of the dynamic risk values for ship operations was carried out with the viewpoint of seafarers. The variable risks in ship operations were determined, and it was evaluated which variables create additional risks to the ship operating in a port. Control measures should be taken, especially when the dynamic risks are in the condition when the visibility is reduced from 4 to 3; the wind force increased up to 4-6 Beafourt scale; at night; when the current speed or tide current speed is more than 1 knots; when the ship type is gas tankers and chemical tankers in cargo operations increase significantly. Control measures and personnel must be informed to carry out the operations more safely.

As a result of the evaluations, it was determined that the increase in the weather status, decreased visibility, the time of operations, and currents or tidal currents cause significant changes on the operations. Ensuring the necessary risk evaluation is made by considering these changes and taking precautions with a dynamic system in which the dynamic risks are included instead of standard risk evaluation forms will improve the safety of operations.

Considering the findings of this study, in further studies, risk factors other than cargo operations can be evaluated in details, and a decision support system can be developed; a system can be developed which will create dynamic risk assessment forms that will consider dynamic conditions.

\section{Acknowledgments}

This article is produced from the initial stages of a PhD thesis research entitled "Developing a Dynamic Risk Assessment Model Based on Failure Mode and Effects Analysis (FMEA) for Safety Ship Operations", which has been executed in a PhD Program in Maritime Transportation Engineering of the Istanbul Technical University Graduate School of Science, Engineering and Technology.

\section{References}

[1] UNCTAD (2019). UNCTAD/RMT/2019. The Review of Maritime Transport 2019. Available at https://unctad.org/ en/PublicationsLibrary/rmt2019_ en.pdf. Accessed 05 February 2020.

[2] Kayserilioğlu, E. (2008). Deniz Taşımacılığı Sektör Profili, İstanbul, s.8.

[3] Villa V., Paltrinieri N., Khan F., Cozzani V. (2016). Towards dynamic risk analysis: a review of the risk assessment approach and its limitations in the chemical process industry. Safety Science, 89:7793. http://dx.doi.org/10.1016/j. ssci.2016.06.002.

[4] Paltrinieri, N., Comfort, L., \& Reniers, G. (2019). Learning about risk: Machine learning for risk assessment. Safety science, 118, 475-486. https://doi. org/10.1016/j.ssci.2019.06.001

[5] Kishore, E. A. \& SMDR, I. V. (2013). Formal Safety Assessment in Maritime Industry-Explanation to IMO Guidelines.

[6] IMO. (2002). Guidelines for Formal Safety Assessment (FSA) for Use in The IMO Rule-Making Process. MSC/ Circ.1023/MEPC/Circ.392.

[7] IMO. (2005). Amendments to The Guidelines for Formal Safety Assessment (FSA) for Use in The IMO Rule-Making Process (MSC/Circ.1023MEPC/Circ.392). 
[8] IMO. (2006). Amendments to The Guidelines For Formal Safety Assessment (FSA) For Use in The IMO Rule-Making Process (MSC/Circ.1023 MEPC/Circ.392).

[9] IMO. (2018). Revised Guidelines for Formal Safety Assessment (FSA) For Use in the IMO Rule-Making Process. MSC-MEPC.2/Circ.12/Rev.2.

[10] IMO. (2000). Resolution A.900(21) adopted on 16 November 1999. Objectives of The Organization in The 2000s. Resolution A.500(XII), A.777(18), A.900(21)

[11] Korçak, M. (2015). İstanbul Boğazı'nda Kimyasalların Deniz Yolu ile Taşınması Sirasinda Meydana Gelen Kazaların Yöntemi." (PhD Thesis). Gazi Üniversitesi.

[12] Toffoli, A., Lefevre, J. M., BitnerGregersen, E., \& Monbaliu, J. (2005). Towards the identification of warning criteria: analysis of a ship accident database. Applied Ocean Research, 27(6), 281-291. https://doi. org/10.1016/j.apor.2006.03.003

[13] Judson, B., Shortreed, J., \& Reid, J. D. (1999). Risk-based Design Method for Aids to Navigation in the St. Lawrence River. Transportation Development Centre.

[14] Kan, E., \& Kişi, H. (2016). Ergonomic Analysis of Navigation Bridge Design: A Qualitative Study On User Perception. Journal of ETA Maritime Science, 4(2), 113-133. doi: 10.5505/ jems.2016.09609

[15] Gucma, S. S. (2010). SAFE SHIPPING ON THE BALTIC SEA. Access Data: 03.19.2020. https://wwwold.prs.pl/_ files/parent262/safe_shipping_on_the_ baltic_sea_2010.pdf

[16] Çiçek, K., \& Topcu, Y. İ. A risk based decision making approach for critical ship operations. Journal of ETA Maritime Science, 6(2), 159-177. https://doi: 10.5505/jems.2018.28199
[17] IMO. (1997). Interim Guidelines for the Application of Formal Safety Assessment to the IMO Rule-Making Process. IMO/MSC Circular 829.

[18] Acar, B. (2007), Risk Değerlendirmesi Temelli Yönetim Anlayıșının Denizcilikte Uygulanması ve Türk Deniz Ticaret Filosunun Risk Değerlendirmesi Yöntemi ile Analizi. (PhD Thesis). Dokuz Eylül Üniversitesi.

[19] Sahin, B., Kum, S. (2015). Risk assessment of Arctic navigation by using improved fuzzy-AHP approach. International Journal of Maritime Engineering, 157(4), 241. http://dx.doi. org/10.3940/rina.ijme.2015.a4.337

[20] Soares, CG., Teixeira, AP. (2001). Risk assessment in maritime transportation. Reliability Engineering \& System Safety, 74.3: 299-309. https://doi. org/10.1016/S0951-8320(01)00104-1

[21] Kalantarnia, M., Khan, F., Hawboldt, K. (2009). Dynamic risk assessment using failure assessment and Bayesian theory. J. Loss Prev. Process Ind. 22 (5), 600-606. http://dx.doi.org/10.1016/ j.jlp.2009.04.006.

[22] Paltrinieri, N., Khan, F., 2016. Dynamic Risk Analysis in the Chemical and Petroleum Industry: Evolution and Interaction with Parallel Disciplines in the Perspective of Industrial Application. Elsevier Science.

[23] Khan, F., Rathnayaka, S., \& Ahmed, S. (2015). Methods and models in process safety and risk management: Past, present and future. Process safety and environmental protection, 98, 116-147. https://doi.org/10.1016/j. psep.2015.07.005

[24] Khan, F., Hashemi, S. J., Paltrinieri, N., Amyotte, P., Cozzani, V., \& Reniers, G. (2016). Dynamic risk management: a contemporary approach to process safety management. Current opinion in chemical engineering, 14, 9-17. https:// doi.org/10.1016/j.coche.2016.07.006 
[25] Ren,Y., Mou,J., Yan, Q., \&Zhang, F. (2011). Study on assessing dynamic risk of ship collision. In ICTIS 2011: Multimodal Approach to Sustained Transportation System Development: Information, Technology, Implementation (pp. 2751-2757). https://doi. org/10.1061/41177(415)346

[26] Yeo, C., Bhandari, J., Abbassi, R., Garaniya, V., Chai, S., \& Shomali, B. (2016). Dynamic risk analysis of offloading process in floating liquefied natural gas (FLNG) platform using Bayesian Network. Journal of Loss Prevention in the Process Industries, 41, 259-269. https://doi. org/10.1016/j.jlp.2016.04.002

[27] Zhang, L., Wu, S., Zheng, W. \& Fan, J. (2018). A dynamic and quantitative risk assessment method with uncertainties for offshore managed pressure drilling phases. Safety science, 104, 39-54. https://doi. org/10.1016/j.ssci.2017.12.033

[28] Pak, J. Y., Yeo, G. T., Oh, S. W. \& Yang, Z. (2015). Port safety evaluation from a captain's perspective: The Korean experience. Safety science, 72, 172181. https://doi.org/10.1016/j. ssci.2014.09.007

[29] Bi, H. \& Si, H. (2012). Dynamic risk assessment of oil spill scenario for Three Gorges Reservoir in China based on numerical simulation. First International Conference on Transportation Information and Safety (ICTIS). Safety science, 50(4), 1112-1118. Wuhan, China. https:// doi.org/10.1016/j.ssci.2011.11.012

[30] Eide, M. S., Endresen, Ø., Breivik, $\emptyset$., Brude, O. W., Ellingsen, I. H., Røang, K., ... \& Brett, P. O. (2007). Prevention of oil spill from shipping by modelling of dynamic risk. Marine Pollution Bulletin, 54(10), 16191633. https://doi.org/10.1016/j. marpolbul.2007.06.013
[31] Dai, H. X., \& Wu, Z. L. (2017). Research on Dynamic Risk Pre-evaluation System for Maritime Traffic Safety in Restricted Visibility. https://doi. org/10.1142/9789813225237_0085

[32] Rokseth, B., \& Utne, I. B. (2015). Dynamic risk assessment of marine systes. In Proceedings of the 25th European Safety and Reliability Conference, ESREL (pp. 725-733). ISBN 978-1-138-02879-1

[33] Balmat, J. F., Lafont, F., Maifret, R., \& Pessel, N. (2009). MAritime RISk Assessment (MARISA), a fuzzy approach to define an individual ship risk factor. Ocean engineering, 36(15-16), 12781286. https://doi.org/10.1016/j. oceaneng.2009.07.003

[34] Yan, X. P., Wan, C. P., Zhang, D., \& Yang, Z. L. (2017). Safety management of waterway congestions under dynamic risk conditions-A case study of the Yangtze River. Applied Soft Computing, 59, 115-128. https:// doi.org/10.1016/j.asoc.2017.05.053

[35] Kuleyin, B., \& Asyali, E. (2007). Limanlarda Gemi Kaynaklı Çevresel Risk Değerlendirmesi ve Yönetimi: Aliağa Limanı Uygulaması.

[36] Veritas, N. (2003). Risk management in marine-and subsea operations. Høvik: Det Norske Veritas.

[37] Kim, K., Kang, H., \& Kim, Y. (2015). Risk assessment for natural gas hydrate carriers: A hazard identification (HAZID) study. Energies, 8(4), 31423164 . https://doi.org/10.3390/ en8043142

[38] Alım, M., \& Gül, M. (2013). Beyin Firtınası Tekniğinin Coğrafi Kavramların Öğretimi ve Kalıcılı̆̆ Üzerindeki Rolü (Erzurum Örneği) The Effect of Brainstorming Technique on Instructing Geographical Concepts (Erzurum Sample). Doğu Coğrafya Dergisi, 18(30). 
[39] Al-Samarraie, H., \& Hurmuzan, S. (2018). A review of brainstorming techniques in higher education. Thinking Skills and Creativity, 27, 78-91. https://doi. org/10.1016/j.tsc.2017.12.002

[40] Arslan, O., \& Er, I. D. (2007). Effects of fatigue on navigation officers and SWOT analyze for reducing fatigue related human errors on board. TransNav, International Journal on Marine Navigation and Safety of Sea Transportation, 1(3).

[41] Ylldırım, U., Uğurlu, Ö., \& Başar, E. (2015). Karaya Oturma Kazalarında İnsan Hatası: Konteyner Gemileri için Örnek Çalışma. https://doi. org/10.5505/jems.2015.57966

[42] Arslan, O., Zorba, Y., \& Svetak, J. (2018). Fault Tree Analysis of Tanker Accidents during Loading and Unloading Operations at the Tanker Terminals. Journal of ETA maritime science, 6(1), 3-16. https://doi.org/10.5505/ jems.2018.29981

[43] Kandemir, Ç. (2019). Application of human reliability analysis to repair \& maintenance operations on-board ships: the case of HFO purifier overhauling. Applied Ocean Research, 88, 317-325. https://doi. org/10.1016/j.apor.2019.04.019

[44] Demirel, H. (2019). Prediction of human error probability for possible gas turbine faults in marine engineering. Journal of ETA Maritime Science, 7(2), 151-163. https://doi.org/10.5505/ jems.2019.49379

[45] Gülseren, Ş., \& KÜLTÜR, S. (1999). Sağlık düzeyi ölçeği'nin Türkçe'ye uyarlanması ve güvenilirliği. Klinik Psikofarmakoloji Bülteni, 9(2).

[46] Rouquette, A., \& Falissard, B. (2011). Sample size requirements for the internal validation of psychiatric scales. International journal of methods in psychiatric research, 20(4), 235-249. https://doi.org/10.1002/mpr.352
[47] Zhang, Z., \& Li, X. M. (2017). Global ship accidents and ocean swell-related sea states. Natural Hazards \& Earth System Sciences, 17(11). https://doi. org/10.5194/nhess-17-2041-2017 